\title{
A Review on the Drugs Approved By US-FDA and DCGI
}

\author{
Article by Vandana \\ Msc Clinical Research, Texila American University \\ Email:-vandanayadav679@texilaconnect.com
}

\section{Introduction}

Drugs : Drug is the chemical substance may be synthesized or derived naturally and is use for its therapeutic effect It plays a vital role in life it is meant to diagnose, mitigate, cure, prevent, or treat or modify the physiological condition. Drug is meant for the safeguard of public health.

Importance of the medicines: medicines are considered to be one of the vital need of the human being. One has to rely upon this once or oftenly in their life time in order to maintain their physical and mental health. In ancient times the illness was considered to be gods wish but after certain period the revolution came and now that is era and till date continuous introduction of drugs to the patient need is available. After continuous Discovery and introduction of the drug the public health is being improved. And the mortality rate compare to ancient time has been reduced.

But there are lot more risks are also associated with a drug along its benefits if not taken cautiously some of major among them are:

1. ADR(adverse drug reaction)

2 drug addiction

3. SAE(serious adverse event)

1 ADR(ADVERSE DRUG REACTION): it is some untoward reaction of a drug other than its therapeutic effects.

2. Drug addiction: these are those drugs also known as opioids drugs some times greatly required. But these drugs as the name suggested are habit forming.

3 SAE:this is known as serious adverse event may be associated with that particular medicine or may be by any other medicines but this event can lead to permanent disfuction of body or may even death of patient.

\section{FDA and its role in drug approval}

The food and drug administration in usa is the organization which responsible for approving and non. approving of the drug. the main aim of FDA is to keep uneffective and unsafe drugs off the market to ensure, protect and increase the good public health. just to ensure that the public good think that if the drug is approved it means it met all the standard for its safety and efficacy when a research molecule is researched then the pharmaceutical company file for IND(investigational new drug)to FDA. The IND filed by company contains whole data of preclinical study i.e trials performed on animals. The number of sheet would be around of 100000 pages in which the whole information about the new drug is written after reviewing the data if the criteria meets the standard then FDA gives approval for clinical trails for that particular drug. Each year FDA approve wide range of new drugs and biological products some of the products are new one or may be already in market but are seeking approval of FDA either for its other therapeutic effect or may be in combination to increase the efficacy.

In order to review the drug in proper way by the FDA the drugs are classified and the new innovative drug is considered to be as NEW MOLECULE ENTITY.

Following are the stages which a drug undergo with to come in market and at every and new stage the company has to file to FDA-:

1. Preclinical trials: inventing product are testing on animals

2. clinical trials-:

Phase 1:perform on healthy volunteers to check the safety of product

Phase 2: Perform on patients to check the safety and efficacy of product 
South American Journal of Clinical Research

Special Edition 2016

Phase 3 :perform on larger population of patient to make sure the safety and efficacy in larger population.

Phase-4:It is also known as post marketing of product done after launching of the product to market on periodic basis.

There are enormous numbers of the drugs which have been researched and many of these are in pipeline to come in market. it take a lot of time around 10-12 yrs it take to come a researched drug from lab to market. only 5 in 5000 drugs are approved for trials on human body after preclinical trial by FDA.

\section{Reasons of not approving much drugs in recent time and then sudden increase in approvals}

The industry and FDA both plays very important role in approval of a drug. There were a sudden decline in the approval of the drugs in past years because of the reason that the pharmaceutical company's r\&d process that is they are not meeting the criteria for safety and efficacy and many other parameters which result into long term decline in pharmaceutical R\&D productivity which ultimately led to decrease in probability of success and increased cost for discovery and development of drug. In order to avoid it the biopharmaceutical company taken the initiative to improve their $\mathrm{r} \& \mathrm{~d}$ status and reducing their fixed costs by outsourcing it to CROS.

\section{The average number of approval rate over time}

From 2004-2012 CDER has 26 NME average approval per anum but in 2012 CDER had approved $39 \mathrm{NME}$ and in 2013 it was 27. The number of approval of the drug remains steady and the maximum number of approval were in 2014 that is total 41 approval of novel drugs in past decades.

1. The reason for sudden increase in approving of new drugs is emergence of drug for life threating dieases through accelerated approval of drug from FDA.

2 . the time reduce by FDA in reviewing data process for NME.

3. the inclination of pharmaceutical companies toward $r \& d$ requirement to meet the standard

The innovative therapies approved in past few years given major advances in the field of oncology, cardiovascular disease, type 2 diabetes, hepatitis $\mathrm{C}$ and in HIV.

\section{The novel drug of 2014-:}

Following are the drugs approved by us-fda in 2014

LIST OF THE NOVEL DRUGS OF 2014

\begin{tabular}{|l|l|l|l|}
\hline Drug name & Active ingredients & $\begin{array}{l}\text { Approval } \\
\text { date }\end{array}$ & What it is used for \\
\hline Opdivo & Nivolumab & $12 / 22 / 2014$ & $\begin{array}{l}\text { To treat patient with } \\
\text { unressectable or metastatics } \\
\text { melanoma who no longer } \\
\text { respond to other drugs }\end{array}$ \\
\hline Rapivab & Peramivir & $12 / 19 / 2014$ & $\begin{array}{l}\text { To treat influenza in adult } \\
\text { patient }\end{array}$ \\
\hline Zerbaxa & Cetolazane/tazobactum & $12 / 19 / 2014$ & $\begin{array}{l}\text { To treat patient with intra } \\
\text { abdominal infection }\end{array}$ \\
\hline Viekira pak & $\begin{array}{l}\text { Ombitasvir, paritaprevir, } \\
\text { ritonair } \\
\text { Tablets }\end{array}$ & $12 / 19 / 2014$ & $\begin{array}{l}\text { To treat patient with chronic } \\
\text { hepatisis c with genotype 1 } \\
\text { infection and complicated urine } \\
\text { infection }\end{array}$ \\
\hline Lynnparza & Olaparib & $12 / 19 / 2014$ & $\begin{array}{l}\text { To treat advance ovarian cancer } \\
\text { To treat acute otititis eternal }\end{array}$ \\
\hline Xtoro & Finafloxacin otic susp & $12 / 17 / 2014$ & $\begin{array}{l}\text { To treat patient with } \\
\text { philodelphia chromosome- }\end{array}$ \\
\hline Blincyto & Blinatumomab & $12 / 3 / 2014$ & \multicolumn{2}{|c|}{} \\
\hline
\end{tabular}




\begin{tabular}{|c|c|c|c|}
\hline & & & negative precursor \\
\hline Esbriet & Pirfenidone & $10 / 15 / 2014$ & $\begin{array}{l}\text { For treat patient with idiopathic } \\
\text { pulmonary fibrosis }\end{array}$ \\
\hline Ofev & Nintedanib & $10 / 15 / 2014$ & $\begin{array}{l}\text { For treat patient with idiopathic } \\
\text { pulmonary fibrosis }\end{array}$ \\
\hline Lumason & $\begin{array}{l}\text { Sulfur hexafluoride lipid } \\
\text { Microsphere }\end{array}$ & $10 / 10 / 2014$ & $\begin{array}{l}\text { For patient whose ultrasound } \\
\text { images is hard to see with } \\
\text { ultrasound wave }\end{array}$ \\
\hline Akynzeo & $\begin{array}{l}\text { Netupitant } \\
\text { palonosetron }\end{array}$ & $10 / 10 / 2014$ & $\begin{array}{l}\text { To treat patient with nose and } \\
\text { vomiting for chemotherapy } \\
\text { patient }\end{array}$ \\
\hline Harvoni & Ledipasvir/sofosbuvir & $10 / 10 / 2014$ & $\begin{array}{l}\text { To treat patient with chronic } \\
\text { hepatitis c with genotype } 1\end{array}$ \\
\hline Trulicity & Dulaglutide & $9 / 18 / 2014$ & $\begin{array}{l}\text { To treat adult with type } 2 \\
\text { diabeties }\end{array}$ \\
\hline Movantik & Naloxegol & $9 / 16 / 2014$ & $\begin{array}{l}\text { To treat opioid induced } \\
\text { constipation }\end{array}$ \\
\hline Keytruda & Pembrolizumab & $9 / 4 / 2014$ & $\begin{array}{l}\text { To treat patient with advance } \\
\text { unresctable melanoma where } \\
\text { other treatments fails to work }\end{array}$ \\
\hline Cerdelga & Eliglustat & $8 / 19 / 2014$ & $\begin{array}{l}\text { For the log term treatment in } \\
\text { adult patient with type } 1 \\
\text { goucher disease }\end{array}$ \\
\hline Plegridy & Peginterferon & $8 / 15 / 2014$ & $\begin{array}{l}\text { To treat patient with relapsing } \\
\text { form of multiple scelerosis }\end{array}$ \\
\hline Belsomra & Suvorexant & $8 / 13 / 2014$ & $\begin{array}{l}\text { To treat patient for inducing } \\
\text { sleep }\end{array}$ \\
\hline Orbactiv & Oritavancin & $8 / 6 / 2014$ & $\begin{array}{l}\text { To treat patient with adult } \\
\text { infection }\end{array}$ \\
\hline Jardiance & Empagliflozin & $8 / 1 / 2014$ & $\begin{array}{l}\text { To improve glycemic control in } \\
\text { adult with type } 2 \text { diabeties }\end{array}$ \\
\hline $\begin{array}{l}\text { Striverdi } \\
\text { respimat }\end{array}$ & Olodaterol & $7 / 31 / 2014$ & $\begin{array}{l}\text { To treat patient with chronic } \\
\text { pulmonary diseases }\end{array}$ \\
\hline Zydelig & Odelalisib & $7 / 23 / 2014$ & $\begin{array}{l}\text { To treat patient with three type } \\
\text { of blood cancer }\end{array}$ \\
\hline Kerydin & Tavaborole & $7 / 7 / 2014$ & $\begin{array}{l}\text { For the treatment of } \\
\text { onychomycosis of toenails }\end{array}$ \\
\hline Beleodaq & Belinostat & $7 / 3 / 2014$ & $\begin{array}{l}\text { To treat patient with peripheral } \\
\text { t-cell lymphoma }\end{array}$ \\
\hline Sivextro & Tedizolid phosphate & $6 / 20 / 2014$ & $\begin{array}{l}\text { To treat adult with skin } \\
\text { infection }\end{array}$ \\
\hline Jubila & Efinaconazole & $6 / 4 / 2014$ & $\begin{array}{l}\text { To treat mil to moderate fungal } \\
\text { infection }\end{array}$ \\
\hline Dalvance & Dalbavancin & $5 / 23 / 2014$ & To treat skin infection \\
\hline
\end{tabular}

The 41 drugs approved by FDA in 2014 contributes a major role in public health and these 41 drugs are placed and divided according to their categories. Few are discussed below:

1. first in class drugs

2. accelerated drug

1. first in class drug: these are those new drugs which are using for new and unique mechanism to treat the medical condition following are the first in class medicines approved by FDA in 2014: 
South American Journal of Clinical Research

Special Edition 2016

1. belsomera 2. blincyto 3. esbriet 4. harvoni 5. impavido 6. kerydin 7. keytruda 8. lynparza 9. Myalopt 10. northera 11. ofev 12. otezia 13. sylvant 14. viekira pak 15. vimizim 16. zontivity 17. zydelig

\begin{tabular}{|l|l|l|}
\hline s.no. & Drugs & Treatment \\
\hline 1 & Harvoni & To treat patient with chromic hepatisis C \\
\hline 2 & Keytruda & To treat patient with unresectable or metastaticmelanoma \\
\hline 3 & zontivity & To reduce risk of thromobotic cardiovascular events \\
\hline & & \\
\hline
\end{tabular}

ACCELERARED APPROVAL: These drugs are those drugs which gets early approval because of their urgent demand in public health for a serious or life threatening illness for better treatment over the used drugs. After approval of these drugs, the drug must undergo additional testing to confirm the benefits.

Following are the drugs approved as accelerated drugs by FDA in 2014:

1. beleodaq 2. keytruda 3. Northera 4. zydelig 5. blincyto 6. lynparza 7. opdivo 8. Zykadia

\begin{tabular}{|l|l|l|}
\hline s.no & Drug & Treatment \\
\hline 1 & Beleodaq & To treat patients wth peripheral T-call lymphoma \\
\hline 2 & Keytruda & To treat patients with melanoma \\
\hline 3 & Northera & To treat patient neurogenic orthostatic hypotension \\
\hline 4 & Zydelig & To treat patient patient with 3 types of cancer \\
\hline 5 & Blincyto & To treat patient with Philadelphia chromosome-negative \\
\hline 6 & lymparza & To treat patient with ovarian cancer \\
\hline 7 & Opdivo & It is human programmed death receptor-1 blocking \\
\hline 8 & zykadia & To treat metastatics non-small cell lung cancer \\
\hline
\end{tabular}

\section{DCGI and its role in approving drugs}

The drug controller general of india was established in 1998 the govt added schedule ' $\mathrm{Y}$ ' to DRUG AND COSMETIC ACT-1940 scheduleY has detailed information for clinical trial and pre-clinical trials. However the pre-clinical trial is not approved in india. Though for the approval for the new drug to become approve and come in the market the same procedure like in us has to follow in india also. For the approval of the drug it is very necessary that the drug should meet all the criteria or guidelines provided in schedule Y. Then the application should be submitted to ethical committee. A clinical trial can only be performed after approval from DCGI for every next phase of the trial for the particular drug the application should be submitted to ethics committee and DCGI. DCGI is having the power to terminate the clinical trial in mid if the result or the data produce is not up to mark. In 2012 the pharmaceutical company were told to submit the safety report for the new drug in six months.

\section{Drugs approved by DCGI in india 2014}

The drugs approved by DCGI are mainly the drug which are already in market or approved already. They come in approval either in combination or with other therapeutic effect unlike previous or for further safety and efficacy purpose. Following are the drugs which were approved by dcgi in 2014-:

\begin{tabular}{|l|l|l|}
\hline Drug & Approval date & Therapeutic use \\
\hline $\begin{array}{l}\text { Tolreridone tartrate extended } \\
\text { release tables } 2 / 4 \mathrm{mg}\end{array}$ & $31 / 01 / 2014$ & $\begin{array}{l}\text { For the treatment of overactive } \\
\text { bladder }\end{array}$ \\
\hline Botezomib for injection 3.5mg & $28 / 01 / 2014$ & $\begin{array}{l}\text { For the treatment of overactive } \\
\text { bladder }\end{array}$ \\
\hline $\begin{array}{l}\text { Paclitaxel inj. Concentrated } \\
\text { for nano dispersion 100 nd } \\
300 \mathrm{mg} \text { topical }\end{array}$ & $\begin{array}{l}\text { For the treatment of breast } \\
\text { cancer after failure of } \\
\text { combination therapy }\end{array}$ \\
\hline $\begin{array}{l}\text { Heparin sodium } \\
\text { solution }\end{array}$ & $\begin{array}{l}\text { For thetreatment of fluctuence } \\
\text { of post infusion superficial } \\
\text { thrombophlebitis }\end{array}$ \\
\hline
\end{tabular}


South American Journal of Clinical Research Special Edition 2016

\begin{tabular}{|c|c|c|}
\hline $\begin{array}{lll}\text { Eltrombopag } & \text { olamine } & \text { tab } \\
25 / 50 \mathrm{mg}\end{array}$ & $7 / 4 / 2014$ & $\begin{array}{l}\text { To treat patient with hepatitis } \\
\text { c }\end{array}$ \\
\hline $\begin{array}{l}\text { Decitabine lyophilized powder } \\
\text { for injection }\end{array}$ & $9 / 4 / 2014$ & $\begin{array}{lll}\text { For elderly } & \text { patient } & \text { to treat } \\
\text { secondary } & \text { acute } & \text { myeloid } \\
\text { leukemia } & & \end{array}$ \\
\hline $\begin{array}{l}\text { Glycopyrronium inhalation } \\
\text { powder }\end{array}$ & $1 / 4 / 2014$ & $\begin{array}{l}\text { To treat chronic obstructive } \\
\text { pulmonary disease }\end{array}$ \\
\hline Micafungin sodium for inj & $2 / 5 / 2014$ & To treat fungal infection \\
\hline Apixaban tab $2.5 \mathrm{mg}$ & $16 / 5 / 2014$ & $\begin{array}{l}\text { Prevention of stroke and } \\
\text { systemic embolism in sdult } \\
\text { patient with non-valvular }\end{array}$ \\
\hline $\begin{array}{l}\text { Mometasone furoate nasal } \\
\text { spray } 50 \mathrm{mcg}\end{array}$ & $21 / 5 / 2014$ & $\begin{array}{l}\text { To treat perennial allergic } \\
\text { rhinitis }\end{array}$ \\
\hline Tadalafil $10 \mathrm{mg}, 20 \mathrm{mg}$ & $30 / 7 / 2014$ & For erectile dysfuction \\
\hline Hydroxychloroquine sulphate & $28 / 7 / 2014$ & $\begin{array}{l}\text { To treat patient with type } \\
\text { 2diabetes }\end{array}$ \\
\hline $\begin{array}{l}\text { Nevirapine extender } \text { release } \\
\text { tab 400mg }\end{array}$ & $1 / 7 / 2014$ & To treat patient with HIV-1 \\
\hline Cerebrolysin inj & $25 / 7 / 2014$ & $\begin{array}{l}\text { To treat amelioration of } \\
\text { cranial injury }\end{array}$ \\
\hline Artesunate powder & 2/7/2014 & $\begin{array}{l}\text { To treat patient with severe } \\
\text { falciparum malaria }\end{array}$ \\
\hline $\begin{array}{l}\text { Lactobacillus brevis } \\
\text { logenges } 100 \mathrm{mg}\end{array}$ & $9 / 8 / 2014$ & $\begin{array}{l}\text { Prevention of radiotherapy } \\
\text { and chemotherapy induced } \\
\text { oral mucositis in cancer } \\
\text { patients }\end{array}$ \\
\hline Rivaroxaban tab15/20mg & $2 / 9 / 2014$ & $\begin{array}{l}\text { To treat patient with deep vein } \\
\text { thrombosis and to prevent } \\
\text { DVT and pulmonary } \\
\text { embolism }\end{array}$ \\
\hline $\begin{array}{l}\text { Hydroxychloroquine tab } \\
300 \mathrm{mg}\end{array}$ & 9/8/2014 & $\begin{array}{l}\text { To treat patient rheumatoid } \\
\text { arthritis with lower body } \\
\text { patient }\end{array}$ \\
\hline Ginko biloba extract & 9/12/2014 & $\begin{array}{l}\text { To treat patient dementia, } \\
\text { vertigo and tinnitus }\end{array}$ \\
\hline $\begin{array}{l}\text { Bendamustine hydrochloride } \\
\text { inj } 25 \mathrm{mg}\end{array}$ & 19/9/2014 & $\begin{array}{l}\text { To treat patient with chronic } \\
\text { lymphocytic leukemia }\end{array}$ \\
\hline Metformin ER750mg & 25/9/2014 & $\begin{array}{l}\text { To improve glycemic control } \\
\text { in type } 2 \text { diabetis }\end{array}$ \\
\hline Sorafenib tsylate tab $200 \mathrm{mg}$ & $25 / 9 / 2014$ & $\begin{array}{l}\text { To treat patient with thyroid } \\
\text { carcinoma refractory }\end{array}$ \\
\hline Deferasirox dt 100/400mg & 26/9/2014 & $\begin{array}{l}\text { Treatment of chronic iron } \\
\text { overload in patient with non- } \\
\text { transfusion } \\
\text { thalassemia }\end{array}$ \\
\hline Imatinib mesilate $100 / 400$ cap & 9/9/2014 & $\begin{array}{l}\text { To treat paediatrics patient } \\
\text { with newly diagnosed } \\
\text { Philadelphia }\end{array}$ \\
\hline Olanzepine pamoate powder & $14 / 10 / 14$ & $\begin{array}{l}\text { To treat patient with } \\
\text { schizophrenia }\end{array}$ \\
\hline Rivastigmine trandermal patch & $28 / 10 / 2014$ & $\begin{array}{l}\text { To treat patient with severe } \\
\text { dementia of the alzheimers } \\
\text { disease }\end{array}$ \\
\hline
\end{tabular}


South American Journal of Clinical Research Special Edition 2016

\begin{tabular}{|l|l|l|}
\hline $\begin{array}{l}\text { Dabigatran etexilate mesilsate } \\
\text { cap 75/110/150mg }\end{array}$ & $17 / 11 / 2014$ & $\begin{array}{l}\text { Treatment of acute deep vein } \\
\text { thrombosis }\end{array}$ \\
\hline Pegasperagase $3750 \mathrm{iu} / 5 \mathrm{ml}$ & $7 / 3 / 2014$ & $\begin{array}{l}\text { Indicated a component of } \\
\text { multi agent chemotherapeutic } \\
\text { regimen for the treatment of } \\
\text { patient with acute } \\
\text { lymphoblastic leukemia }\end{array}$ \\
\hline $\begin{array}{l}\text { Tulobuterol transdermal patch } \\
0.5 \mathrm{mg} / 1.0 \mathrm{mg} / 2.0 \mathrm{mg}\end{array}$ & $\begin{array}{l}\text { To treat patient with asthma } \\
\text { and COPD }\end{array}$ \\
\hline Azacitidine100mginj & $\begin{array}{l}\text { TO treat adult patient wth } \\
\text { myelodysplastic syndrome }\end{array}$ \\
\hline Azacitidine & $29 / 4 / 2014$ & $\begin{array}{l}\text { Same as above } \\
\text { Ro treat patient with mtastatic } \\
\text { colorectal cancer }\end{array}$ \\
\hline Roflumilast $500 \mathrm{~m}$ & $\begin{array}{l}\text { For the treatment of severe } \\
\text { COPD }\end{array}$ \\
\hline $\begin{array}{l}\text { Relapsing remitting } \\
\text { tab }\end{array}$ & $1 / 7 / 2014$ & \multicolumn{2}{|c|}{} \\
\hline
\end{tabular}

\section{Conclusion}

The revolution in drug discovery and its approval is proved as boon for public health. It results in improved health both mentally and physically in human race. The pace of drug approval is quite high in present time as compare to past few years. The high rate of approval of drug is good initiative by the government authorities to maintain and sustain good public health. Specially in case of life threatening illness like cancer, HIV, cardiovascular and many more. By approving these drugs on fast basis and keeping all quality and standard of these drugs in mind many lives can be saved in time. This is good move for both india and usa. Population. Specially in india as india is developing country and illness rate and variety of illness is more here than in any other country and due to lack of heigene and lack of awareness the chances are more to spread of dieases in contagious way specially in rural area. So it is very necessary demand for approval of these drugs so that preventive action can be taken against illness in time.

\section{References}

[1]. Cdsco.nic.in/forms/searchmore. Aspx?1d=11(approval-central drug standard control organization)

[2]. Llinch 1, medical nemesis: the appropriation of health. London:calder and boyars 1975 Adorable science

[3]. Mckeown T. the role of medicines dream, mirage or nemesis/London: Nuffield provincial hospitals trust, 1976

[4]. u.s food and drug administration control for drug evaluation \&control

[5]. www.fda.govt/drugs/development process/

[6]. www.srmunir.ac.in/.../responsibilies_of-regulatory_authority 